\title{
MODEL PENGENTASAN SIKAP PROKRASTINASI AKADEMIK (STUDI PENGEMBANGAN BERBASIS COGNITIVE BEHAVIOR THERAPY)
}

\author{
Rahmatia \\ Bimbingan dan Konseling, STIKIP Andi Mattappa \\ email: rahmatia@gmail.com \\ Nur Halim \\ Bimbingan dan Konseling, Program Pascasarjana UNM \\ email: pershalim@gmail.com.
}

\begin{abstract}
This study aims to determine (1) picture of the level of demand reduction model of academic procrastination attitude of high school students in Makassar. (2) description of a hypothetical model of academic procrastination attitude alleviation based cognitive behavior therapy. (3) description of the model-based academic procrastination attitude alleviation of cognitive behavior therapy that terkembangkan. This study uses the approach of research and development as well as qualitative and quantitative methods. The study population was high school in the city of Makassar with a sample of 12 schools. The results showed. (1) the level of demand reduction model of academic procrastination attitude of high school students in Makassar at the high category. (2) The hypothetical model is the beginning of the preparation of academic procrastination attitude alleviation models. The model was developed based on the needs assessment. The model consists of several components such as rational, objectives, scope, target population, the basic assumptions, the working principle, system support services, the role of counselor, procedure implementation, evaluation model, and the model guidelines. (3) terkembangkan models are models that have gone through the stage of model validation both by $\mathrm{BK}$ experts and practitioners in schools so that the model has been tested constructs / content and descriptive. Therefore, the model terkembangkan generated in this study is a model that is ready to be used in schools to help students in eliminating academic procrastination habit is often done.
\end{abstract}

\section{Keywords: . Academic Procrastination, Cognitive Behavior}

\begin{abstract}
Abstrak: Penelitian ini bertujuan untuk mengetahui (1) gambaran tingkat kebutuhan model pengentasan sikap prokrastinasi akademik siswa SMA di Makassar. (2) gambaran model hipotetik pengentasan sikap prokrastinasi akademik berbasis cognitive behavior therapy. (3) gambaran model pengentasan sikap prokrastinasi akademik berbasis cognitive behavior therapy yang terkembangkan. Penelitian ini menggunakan pendekatan penelitian dan pengembangan serta metode kualitatif dan kuantitatif. Populasi penelitian ini adalah SMA yang ada di kota Makassar dengan sampel sebanyak 12 sekolah. Hasil penelitian menunjukkan. (1) tingkat kebutuhan model pengentasan sikap prokrastinasi akademik siswa di SMA Makasar berada pada kategori tinggi. (2) model hipotetik merupakan awal dari penyusunan model pengentasan sikap prokrastinasi akademik. Model ini disusun berdasarkan hasil need assesment. Model ini terdiri dari beberapa komponen seperti rasional, tujuan, ruang lingkup, populasi sasaran, asumsi dasar, prinsip kerja, pendukung sistem layanan, peranan konselor, prosedur pelaksanaan, evaluasi model, dan panduan model. (3) model terkembangkan adalah model yang telah melalui tahap validasi model baik yang dilakukan oleh ahli BK dan praktisi di sekolah sehingga
\end{abstract}


model tersebut telah teruji secara konstruk/isi maupun secara deskriptif. Karena itu, model terkembangkan yang dihasilkan dalam penelitian ini adalah model yang siap untuk digunakan di sekolah untuk membantu siswa dalam menghilangkan kebiasaan prokrastinasi akademik yang sering dilakukan.

Kata Kunci: Prokratinasi Akademik, Cognitive behavior.

\section{PENDAHULUAN}

Disiplin, kreatif dan memiliki etos kerja yang tinggi adalah indikator sumber daya manusia yang berkualitas dan fondasi yang amat menentukan. Seseorang dikatakan mempunyai kualitas sumber daya manusia yang tinggi jika dia dapat menunjukkan perilaku yang mencerminkan adanya kedisiplinan, kreativitas maupun etos kerja yang tinggi dalam mengerjakan tugas-tugasnya. Sikap disiplin merupakan sikap yang harus ditingkatkan, karena memberi manfaat dan sumbangan yang besar, apalagi pada negara yang masih berkembang seperti negara Indonesia. Berhubungan dengan manusia yang berkualitas, dalam khasanah ilmiah psikologi terdapat istilah prokrastinasi yang menunjukkan suatu perilaku yang tidak disiplin dalam penggunanaan waktu.

Istilah prokrastinasi berasal dari bahasa Latin procrastination yang berarti menangguhkan atau menunda (pekerjaan) sampai hari berikutnya. Prokrastinasi akademik dan nonakademik sering menjadi istilah yang digunakan oleh para ahli untuk membagi jenis-jenis tugas yang diprosraktinasi. Prokrastinasi non-akademik adalah penundaan yang dilakukan pada jenis tugas non-formal atau tugas yang berhubungan dengan kehidupan sehari-hari, misalnya tugas rumah tangga, tugas sosial, tugas kantor dan lain sebagainya. Prokrastinasi akademik adalah jenis penundaan yang dilakukan pada jenis tugas formal yang berhubungan dengan tugas akademik, misalnya tugas sekolah atau tugas kursus. Dapat dikatakan bahwa prokrastinasi akademik adalah suatu penundaan yang dilakukan secara sengaja dan berulang-ulang dengan melakukan aktifitas lain yang tidak diperlukan dalam pengerjaan tugas sekolah. Oleh karena itu, siswa yang mempunyai kecenderungan untuk menunda, atau tidak segera memulai suatu kerja, ketika menghadapi suatu tugas sekolah disebut sebagai orang yang melakukan prokrastinasi, atau biasa disebut "prokrastinator".

Prokrastinasi adakalanya dilakukan tanpa alasan. Akan tetapi kebanyakan prokrastinasi berkaitan dengan rasa takut gagal, tidak suka pada tugas yang diberikan, menentang dan melawan kontrol, sifat ketergantungan dan kesulitan dalam membuat keputusan. Prokrastinasi juga biasa dilakukan karena prokrastinator merasa menemukan aktivitas lain yang dirasa lebih menyenangkan daripada mengerjakan kewajibannya. Prokrastinator sadar betul bahwa tugasnya, bagaimanapun juga tetap harus dikerjakan. Akan tetapi dia enggan memulainya dan lebih memilih melakukan aktivitas lain. Pada awalnya prokrastinator merasa nyaman dengan prokrastinasi yang ia lakukan, tapi kemudian ia akan merasa bersalah dan menjalani kehidupannya dengan rasa bersalah tersebut.

Mc.Cown dan De Simone (Ferrari, et al, 1995: 22) menjelaskan bahwa faktor penyebab prokrastinasi dapat ditinjau dengan menggunakan perspektif psikoanalisa dan perspektif cognitive-behavior, namun dalam penelitian ini peneliti akan menggunakan perspektif cognitive-behavior untuk menjelaskan terbentuknya perilaku ini. Dalam perspektif cognitive-behavior, perilaku prokrastinasi terjadi karena:

1. Pemikiran yang salah (irrational belief) mengenai waktu yang tepat untuk memulai suatu pekerjaan Knaus, (Ferrari, et al, 1995: 35). Misalnya individu memiliki pemikiran bahwa dirinya sebaiknya mulai mengerjakan tugas tersebut ketika sudah mempunyai motivasi yang kuat untuk bekerja.

2. Lemahnya self-statement untuk pengendalian diri dan kuatnya self-statement untuk membuat permaafan atau mencari alasan terhadap penundaan pekerjaan Greco, (Ferrari, et al, 1995 : 36). 
3. Adanya pemahaman yang kurang tepat mengenai penyebab kegagalan yang berkaitan dengan masa lalunya. Dimana kegagalan di masa lalu dipahami sebagai akibat dari suatu faktor yang tidak dapat dikendalikan oleh individu. Jadi individu memiliki pemikiran bahwa seberapa keras individu berusaha namun kecil kemungkinan akan meraih keberhasilan. Taylor (Ferrari, et al, 1995: 37).

4. Reinforcer yang diterima individu ketika menunda pekerjaan bersifat menyenangkan sehingga individu akan cenderung untuk mengulang kembali perilaku prokrastinasi. Skinner (Ferrari, et al, 1995: 26). Hal ini terkait dengan kondisi psikologis seseorang yang lebih mudah menerima immediate reinforcer daripada memikirkan punishment yang datangnya belakangan atau delayed punishers (Martin, 1996: 314).

Menurut Ferrari, et al (1995: 11) perilaku prokrastinasi mengandung 4 aspek, yaitu: rendahnya intensi untuk mulai menyelesaikan tugas, memiliki standard hasil kerja yang tidak optimal, sifat pekerjaan yang ditunda oleh prokrastinator adalah penting, ada emosi marah, ketidakpuasan ataupun emosi negatif lainnya ketika melakukan pekerjaan yang ditunda. Kecenderungan prokrastinasi akademik yang dilakukan oleh mahasiswa dapat berpengaruh pada prestasi belajar yang mereka capai karena kurang maksimalnya proses belajar yang mereka lakukan. Hal ini dibuktikan lewat penelitian Akinsola, Tella \& Tella (2007: 363-369) yang menunjukkan bahwa prestasi matematika pada mahasiswa di Nigeria yang rendah karena sering melakukan prokrastinasi akademik.

Prokrastinasi pada siswa banyak berakibat negatif, diantaranya adalah siswa akan mendapatkan nilai lebih rendah, menarik diri terhadap pendidikan yang lebih tinggi, memiliki tingkat kehadiran di kelas yang lebih rendah, dan dikeluarkan dari sekolah. Prokrastinasi pada tugas juga memiliki akibat terhadap emosi seseorang. Ketika seseorang sadar bahwa dia melakukan prokrastinasi, maka mereka mengalami berbagai perasaan dalam dirinya diantaranya adalah rendah diri, mengutuk diri, rasa bersalah, merasa melakukan kecurangan, mengalami ketegangan, kepanikan, dan kecemasan dalam diri (Binder, 2000).
Berdasarkan pengamatan terhadap perilaku siswa dan data yang diperoleh dari wawancara dengan konselor di SMKN 3 Makassar diperkirakan dalam satu kelas yang terdiri dari 35 siswa, terdapat $20 \%$ siswa yang kerapkali menunda pekerjaan, bentuk penundaan yang dilakukan siswa diantaranya adalah terlambat masuk ke kelas saat pelajaran sudah dimulai, tidak mengerjakan PR di rumah atau mengerjakan PR di sekolah dan terlambat mengumpulkan tugas dari guru.

Berdasarkan fenomena di atas, maka perlu adanya upaya dalam menangani masalah prokrastinasi siswa. Hal ini dilakukan dengan harapan agar perilaku prokrastinasi dapat diatasi dan tidak mengganggu kualitas perilaku dan hasil belajar siswa. Upaya tersebut dapat ditempuh melalui cognitive behavior therapy karena prokrastinasi siswa adalah suatu perilaku tidak adaptif yang diakibatkan oleh pemikiranpemikiran (kognisi) tidak rasional. Berdasarkan pendapat Ellis (Ferrari,1995) prokrastinator atau para pelaku prokrastinasi umumnya tidak percaya pada kemampuan mereka untuk menyelesaikan tugas, sebagai konsekuensinya mereka menunda untuk memulai menyelesaikan tugas. Melalui cognitive behavior therapy, individu diubah perilaku tidak adaptifnya dengan terlebih dahulu menantang aspek kognisi dan ketakutan irasionalnya yang mendasarinya agar menjadi lebih realistis. (Ferrari dalam Binder, 2000).

Berdasarkan hasil temuan dan pengamatan yang dilakukan oleh peneliti dalam membaca literatur mengenai cognitive behavior therapy mengindikasikan bahwa konsep CBT dapat memberikan kontribusi kepada konselor di sekolah berupa konsep dan keterampilan konseling tertentu yang dapat digunakan untuk membantu konseli/siswa dalam mengatasi permasalahan yang dihadapinya terutama dalam hal kebiasaan prokrastinasi siswa. Namun selama ini kehadiran CBT khususnya di sekolah-sekolah yang ada di Makassar masih sangat jarang konselor di sekolah mengaplikasikan setiap tahap dalam CBT untuk menangani masalah-masalah yang dihadapi oleh siswa. Sementara itu, berdasarkan kajian literatur yang peneliti lakukan menunjukkan bahwa konsep-konsep CBT mengandung aspek yang dapat dikembangkan dalam bentuk panduan pelaksanaan konseling bagi siswa. Lalu, bagaimanakah bentuk panduan pelaksanaan cognitive behavior therapy (CBT) 
bagi siswa yang mengalami prokrastinasi akademik? Pertanyaan inilah yang menjadi fokus kajian dalam penelitian ini. Melalui pengkajian yang bersifat pengembangan diharapkan dapat memperoleh pemahaman yang lebih komprehensif sehingga dapat dijadikan bahan masukan bagi pendidikan para konselor maupun calon konselor.

\section{Rumusan Masalah}

Berdasarkan uraian latar belakang tersebut di atas, maka rumusan masalah dalam penelitian ini, adalah:

1. Bagaimana gambaran tingkat kebutuhan model pengentasan sikap prokrastinasi akademik siswa SMA di Makassar?.

2. Bagaimana gambaran model hipotetik pengentasan prokrastinasi akademik berbasis cognitive behavior therapy?

3. Bagaimana gambaran model pengentasan sikap prokrastinasi akademik berbasis cognitive behavior therapy yang terkembangkan?.

\section{METODE}

\section{Model Pengembangan}

Penelitian ini dilakukan dengan menggunakan pendekatan "Penelitian Pengembangan" (Research and Development). Menurut Borg and Gall (1983: 782), yang dimaksud dengan model penelitian dan pengembangan adalah "a process used develop and validate educational product". Penelitian ini juga disebut 'research based development', yang muncul sebagai strategi dan bertujuan untuk meningkatkan kualitas pendidikan. Selain untuk mengembangkan dan memvalidasi hasil-hasil pendidikan. Penelitian Research and Development ini dimanfaatkan untuk menghasilkan model pengembangan model pengentasan sikap prokrastinasi akademik siswa berbasis CBT.

Peneliti melakukan Pengembangan Model Pengentasan Sikap Prokrastinasi Akademik Siswa Berbasis CBT. Dalam melakukan penelitian ini untuk menghilangkan kebiasaan prokrastinasi akademik siswa di sekolah, adapun produk yang dihasilkan berupa Panduan Model Pengentasan Sikap Prokrastinasi Akademik Berbasis CBT.

\section{Variabel Pengembangan}

Penelitian ini terdiri dari dua peubah yang dikaji yaitu pengentasan sikap prokrastinasi akademik berbasis cognitive behavior therapy. Sikap prokrastinasi akademik sebagai peubah terikat atau yang dipengaruhi (independent) sedangkan cognitive behavior therapy sebagai peubah bebas atau yang mempengaruhi (dependen)

\section{Subjek Penelitian}

Subjek penelitian ini adalah guru bimbingan dan konseling (konselor), serta siswa. Pada tahap validasi dan pengembangan model, kegiatan penelitian berkaitan dengan kelayakan isi/konstruk dan kelayakan operasional model. Subjek penelitian pada tahap ini adalah ahli konseling dan konselor di sekolah. Adapun tahap pelatihan dan simulasi model diberikan kepada sejumlah guru pembimbing/konselor untuk mengetahui gambaran pelaksanaan model tersebut. Gambaran rinci subjek penelitian, terlihat pada tabel 3.1 berikut:

Tabel 3.1: Keadaan Subjek Penelitian Pengembangan Model

\begin{tabular}{lcc}
\hline \multicolumn{1}{c}{ Tahap Kegiatan Penelitian } & Jenis Subjek & Jumlah \\
\hline \multirow{2}{*}{ Asesmen Kebutuhan } & Konselor & 8 Orang \\
\cline { 2 - 3 } & Siswa & 40 Orang \\
\hline Validasi Isi Model & Pakar konseling & 3 Orang \\
\hline Validasi Empirik Model & Konselor/Guru BK & 12 Orang \\
\hline Pelatihan dan Simulasi Model & Konselor/Guru BK & 5 Orang \\
\hline
\end{tabular}

\section{Defenisi Konsep}

1. Pengembangan Model ialah serangkaian kegiatan mendesain, membuat, menilai dan merevisi suatu produk atau model yang telah atau akan dikembangkan. Bentuknya berupa model fisik (maket, bentuk prototype atau 
modul), model citra (gambar rancangan, citra computer), atau rumusan matematis. Dalam hal ini model yang akan dikembangkan adalah model pengentasan sikap prokrastinasi akademik siswa berbasis CBT.

2. Prokrastinasi akademik yaitu suatu perilaku menuda-nunda pekerjaan yang biasa dilakukan oleh kebanyakan orang. Penundaan itu dilakuka oleh seseorang terhadap tugas atau suatu pekerjaan. Mereka memiliki kecenderungan untuk menunda atau mengulur waktu untuk mengerjakan suatu pekerjaan yang sudah menjadi tugas dan kewajiban mereka.

3. Cognitive behavior therapy adalah pendekatan konselig yang menitik beratkan pada restrukturisasi atau pembenahan kognitif yang meyimpang akibat kejadian yang merugikan baik secara fisik maupun psikis.

\section{Prosedur Pengembangan}

Model pengembangan yang digunakan dalam penelitian ini mengacu pada model pengembangan yang dikemukakan oleh Borg and Gall (1983) yang terdiri dari 10 tahapan umum, tahapan tersebut adalah:

1. Riset awal dan pengumpulan informasi (research and information collecting)

2. Perencanaan (planning)

3. Penyusunan format model awal (develop

preliminary form of product)

4. Melakukan uji coba tahap awal (preliminary field Testing)

5. Melakukan revisi model utama (main product revision)

6. Melakukan uji coba lapangan model utama (main field testing)

7. Melakukan revisi model operasiponal (Operational product revision)

8. Melakukan uji model operasional (Operational field testing)

9. Melakukan revisi model (final product revision), dan

10. Mendesiminasikan dan mengimplementasikan produk. (desimination and distribution)

Tempat dan Waktu Pengembangan

Penelitian pengembagan ini dilakukan di SMA di makassar setelah terlebih dahulu mengadakan observasi untuk memperoleh data/informasi. Siswa SMA tersebut dipilih karena pada dasarnya masa sekolah merupakan masa dimana siswa akan mengalami banyak perubahan baik dari segi perilaku maupun dari segi pola pikirnya. Dalam hal ini proses belajar siswa di sekolah sangatlah penting untuk memaksimalkan prestasi belajar siswa di sekolah, oleh karena itu peneliti menggunakan model pengentasan sikap prokrastinasi akademik siswa berbasis cognitive behavior therapy.

\section{Pengembangan Instrumen Pengumpulan Data}

Berdasarkan subyek penelitian dan jenis data primer yang akan dikumpulkan, maka ada beberapa jenis alat pengumpulan data yang digunakan, seperti:

1. Kuesioner
a. Kuesioner Pengentasan Sikap Prokrastinasi Akademik Siswa
b. Kuesioner Asesmen Kebutuhan Konseling
c. Kuesioner Kelayakan Model

2. Wawancara (interview)

Selain kuesioner, alat pengumpulan data yang perlu dikembangkan adalah pedoman wawancara.

3. Observasi

Penelitian ini juga menggunakan pedoman observasi, pedoman observasi tersebut digunakan dalam kegiatan uji keterlaksanaan model.

\section{HASIL DAN PEMBAHASAN}

Gambaran Tingkat Kebutuhan Model Pengentasan Sikap Prokrastinasi Akademik Siswa SMA Di Makassar

Rangkaian kegiatan dalam penyusunan model diawali dengan assesmen kebutuhan. Pelaksanaan assesmen kebutuhan dilakukan di 4 sekolah yang terdiri dari SMK, SMA Negeri, SMA Swasta, dan MAN yang semuanya berada di kota makassar. Adapun alat pengumpulan data yang digunakan peneliti dalam melakukan assesmen kebutuhan ini adalah membagikan angket need assesment pada 2 orang guru dan 10 orang siswa pada masing-masing sekolah tersebut.

\section{1) Eksistensi Program Pengentasan Sikap Prokrastinasi Akademik Siswa}

Eksistensi program-program pengembangan model pengentasan sikap prokrastinasi akademik 
adalah tidak adanya program-program yang bertujuan untuk mengatasi kebiasaan prokrastinasi akademik siswa di sekolah. Program-program yang dimaksud dapat berupa kegiatan-kegiatan yang membantu siswa untuk menghilangkan sikap prokrastinasi akademiknya. Gambaran rinci hasil assesmen tentang eksistensi model pengentasan sikap prokrastinasi akademik berbasis cognitive behavior therapy dapat dilihat pada pada tabel 4.1 berikut ini.

Tabel 4.1: Eksistensi Model Pengentasan Sikap Prokrastinasi Akademik Siswa.

\begin{tabular}{|c|c|c|c|c|c|c|}
\hline \multirow{3}{*}{ Reponden } & \multicolumn{4}{|c|}{ Eksistensi Program } & \multirow{2}{*}{\multicolumn{2}{|c|}{ Jumlah }} \\
\hline & \multicolumn{2}{|c|}{ Ada } & \multicolumn{2}{|c|}{ Tidak Ada } & & \\
\hline & $\mathbf{F}$ & $\%$ & $\mathbf{F}$ & $\%$ & $\mathbf{F}$ & $\%$ \\
\hline Konselor & 0 & - & 8 & 100 & 8 & 100 \\
\hline Siswa & 9 & 22.5 & 31 & 77.5 & 40 & 100 \\
\hline$\sum$ & 17 & 35.41 & 31 & 64.58 & 48 & 100 \\
\hline
\end{tabular}
konseli untuk menghilangkan kebiasaan

prokrastinasi akademik siswa di sekolah tidak ada atau belum ada. Hal ini menunjukkan bahwa dari segi kebutuhan perlu dipertimbangkan untuk diadakan program-program yang dapat membantu konseli/siswa dalam mengentaskan sikap prokrastinasi akademik dan mampu

\section{2) Urgensi Program Pengentasan Sikap Prokrastinasi Akademik Siswa}

Urgensi program pengentasan sikap prokrastinasi akademik siswa berbasis cognitive behavior therapy merupakan gambaran tentang pentingnnya model tersebut di sekolah, adapun gambaran hasil assesmen kebutuhan tentang hal ini dapat dilihat pada tabel 4.2 berikut:

Tabel 4.2: Urgensi Model Pengentasan Sikap Prokrastinasi Akademik

\begin{tabular}{|c|c|c|c|c|c|c|c|c|c|c|}
\hline \multirow{3}{*}{ Reponden } & \multicolumn{8}{|c|}{ Urgensi Program } & \multirow{2}{*}{\multicolumn{2}{|c|}{ Jumlah }} \\
\hline & \multicolumn{2}{|c|}{ Sangat Penting } & \multicolumn{2}{|c|}{ Penting } & \multicolumn{2}{|c|}{$\begin{array}{l}\text { Kurang } \\
\text { Penting }\end{array}$} & \multicolumn{2}{|c|}{ Tidak Penting } & & \\
\hline & $\mathbf{F}$ & $\%$ & f & $\%$ & $\mathbf{F}$ & $\%$ & $\mathbf{f}$ & $\%$ & f & $\%$ \\
\hline Konselor & 7 & 87.5 & 1 & 12.5 & - & 0 & - & 0 & 8 & 100 \\
\hline Siswa & 21 & 52.5 & 19 & 47.5 & - & 0 & - & 0 & 40 & 100 \\
\hline$\sum$ & 28 & 58.33 & 20 & 41.67 & - & 0 & - & 0 & 48 & 100 \\
\hline
\end{tabular}

Hasil assesmen kebutuhan sebagaimana yang ditunjukkan pada tabel 4.2 tersebut menunjukkan bahwa pada umumnya siswa dan guru bimbingan konseling menganggap bahwa program untuk model pengentasan sikap prokrastinasi akademik berbasis cognitive behavior therapy itu sangatlah penting. Hal tersebut memberi gambaran bahwa program untuk membantu siswa dalam menghilangkan kebiasaan prokrastinasi akademiknya sangatlah dibutuhkan oleh siswa.

\section{3) Bentuk Pelaksanaan Pengentasan Sikap Prokrastinasi Akademik Siswa}

Bentuk pelaksanaan model pengentasan sikap prokrastinasi akademik berbasis cognitive behavior therapy ini, lebih kepada bagaimana bentuk pelaksanaan program pengentasan sikap prokrastinasi akademik berbasis cognitive behavior therapy akan dilaksanakan, apakah itu dalam bentuk konseling individu, konseling kelompok atau dalam bentuk layanan klasikal di kelas. Adapun hasil need assesment mengenai bentuk pelaksanaan tersebut dapat dilihat pada tabel 4.3 berikut: 
Tabel 4.3: Bentuk Pelaksanaan Model Pengentasan Sikap Prokrastinasi Akademik Siswa

\begin{tabular}{|c|c|c|c|c|c|c|c|c|}
\hline \multirow{3}{*}{ Reponden } & \multicolumn{6}{|c|}{ Bentuk Pelaksanaan Program } & \multirow{2}{*}{\multicolumn{2}{|c|}{ Jumlah }} \\
\hline & \multicolumn{2}{|c|}{ Konseling Individu } & \multicolumn{2}{|c|}{$\begin{array}{c}\text { Konseling } \\
\text { Kelompok }\end{array}$} & \multicolumn{2}{|c|}{$\begin{array}{l}\text { Layanan } \\
\text { Klasikal }\end{array}$} & & \\
\hline & $\mathbf{f}$ & $\%$ & $\mathbf{f}$ & $\%$ & $\mathbf{f}$ & $\%$ & f & $\%$ \\
\hline Konselor & 1 & 12.5 & 7 & 87.5 & - & 0 & 8 & 100 \\
\hline Siswa & 13 & 32.5 & 27 & 67.5 & - & 0 & 40 & 100 \\
\hline$\sum$ & 14 & 29.17 & 34 & 70.83 & - & 0 & 48 & 100 \\
\hline
\end{tabular}

Ditunjukkan pada grafik 4.3 di atas, sebagian besar siswa dan konselor menyatakan bahwa bentuk pelaksanaan model pengentasan sikap prokrastinasi akademik siswa berbasis cognitive behavior therapy dalam berbentuk konseling kelompok. Konseling kelompok merupakan jenis layanan yang memungkinkan konseli memperoleh kesempatan untuk pembahasan dan pengentasan masalah yang dialaminya melalui dinamika kelompok. Hal ini menegaskan bahwa model pengentasan sikap prokrastinasi akademik dilaksanakan dalam betuk konseling kelompok sehingga dalam pelaksanaannya nanti semua konseli dapat saling membantu dan memberi masukan.

\section{4) Kendala Model Pengentasan Sikap}

\section{Prokrastinasi Akademik Siswa}

Kendala yang dimaksudkan adalah hal-hal yang dapat menghambat pelaksanaan program pengembangan atau peningkakatan prestasi belajar siswa di sekolah. Adapun kendala yang dialami oleh konselor dan siswa dalam pelaksanaan program pengembangan model pengentasan sikap prokrastinasi akademik siswa yang diperoleh dari hasil asesmen kebutuhan disekolah dapat dilihat pada tabel 4.4 berikut:

Tabel 4.4: Kendala Program Pengembangan Model Pengentasan Sikap Prokrastinasi Akademik Siswa

\begin{tabular}{|c|c|c|c|c|c|c|c|c|}
\hline \multirow{3}{*}{ Reponden } & \multicolumn{6}{|c|}{ Kendalam Program } & \multirow{2}{*}{\multicolumn{2}{|c|}{ Jumlah }} \\
\hline & \multicolumn{2}{|c|}{ Belum Ada Model } & \multicolumn{2}{|c|}{$\begin{array}{c}\text { Tenaga Profesional/ } \\
\text { Arahan Konselor }\end{array}$} & \multicolumn{2}{|c|}{$\begin{array}{c}\text { Tidak Adanya } \\
\text { Waktu }\end{array}$} & & \\
\hline & $\mathbf{f}$ & $\%$ & $\mathbf{F}$ & $\%$ & f & $\%$ & $\mathbf{F}$ & $\%$ \\
\hline Konselor & 8 & 100 & - & 0 & - & 0 & 8 & 100 \\
\hline Siswa & 5 & 12.5 & 27 & 67.5 & 8 & 20 & 40 & 100 \\
\hline$\sum$ & 13 & 27.08 & 27 & 56.25 & 8 & 16.67 & 48 & 100 \\
\hline
\end{tabular}

Tabel 4.4 tersebut menunjukkan bahwa kendala utama yang dihadapi dalam pelaksanakan program pengembangan model pengentasan sikap prokrastinasi akademik siswa adalah belum adanya model yang dapat dipedomani. Hasil assesmen ini mengindikasikan bahwa diperlukan sebuah model yang dapat dijadikan sebagai panduan dalam melaksanakan program pengembangan model pengentasan sikap prokrastinasi akademik siswa di sekolah.

\section{5) Sigifikansi Model Pengentasan Sikap} Prokrastinasi Akademik Siswa

Signifikansi model pengentasan sikap prokrastiasi akademik siswa di sekolah merupakan gambaran tentang pentingnnya pengadaan model dalam pelaksanaan program untuk membantu siswa menghilangkan kebiasaan prokrastinasi akademik siswa. Adapun gambaran hasil assesmen kebutuhan tentang hal ini dapat dilihat pada tabel 4.5 berikut:

Tabel 4.5: Signifikansi Model Pengentasan Sikap Prokrastinasi Akademik Siswa

\begin{tabular}{|c|c|c|c|c|c|c|c|c|c|c|}
\hline \multirow{3}{*}{ Reponden } & \multicolumn{8}{|c|}{ Signifikansi Model } & \multirow{2}{*}{\multicolumn{2}{|c|}{ Jumlah }} \\
\hline & \multicolumn{2}{|c|}{$\begin{array}{c}\text { Sangat } \\
\text { Dibutuhkan }\end{array}$} & \multicolumn{2}{|c|}{ Dibutuhkan } & \multicolumn{2}{|c|}{$\begin{array}{c}\text { Kurang } \\
\text { Dibutuhkan }\end{array}$} & \multicolumn{2}{|c|}{$\begin{array}{c}\text { Tidak } \\
\text { Dibutuhkan }\end{array}$} & & \\
\hline & $\mathbf{F}$ & $\%$ & $\mathbf{f}$ & $\%$ & $\mathbf{F}$ & $\%$ & $\mathbf{f}$ & $\%$ & $\mathbf{f}$ & $\%$ \\
\hline Konselor & 8 & 100 & - & 0 & - & 0 & - & 0 & & 100 \\
\hline
\end{tabular}


Pada tabel 4.5 menunjukkan bahwa model pengentasan sikap prokrastinasi akademik siswa di sekolah sangatlah dibutuhkan. Hasil ini memberi penegasan bahwa dalam membantu siswa untuk menghilangkan kebiasaan prokrastinasi dibidang akademik dibutuhkan sebuah model atau panduan dalam pelaksanaannya. Model yang dimaksud adalah bentuk program yang sistematik dan prosedural yang dibangun dari landasan filosofis dan operasional dalam meningkatkan prestasi akademik siswa di sekolah.
Selain itu asesmen kebutuhan juga dilakukan untuk mengetahui bagaimana gambaran awal tingkat prokrastinasi akademik siswa pada beberapa SMA di kota Makassar. Dalam hal ini peneliti menggunakan kuesioner atau angket prokrastinasi akademik yang sebelumnya telah melalui tahap uji validitas dan uji coba lapangan. Angket atau kuesioner tersebut diberikan kepada 40 orang siswa yang tersebar di 4 SMA di Kota Makassar. Adapun gambaran tingkat prokrastinasi akademik siswa tersebut dapat dilihat pada tabel 4.6 berikut ini.

Tabel 4.6. Data Tingkat Prokrastinasi Akademik Siswa di Beberapa SMA di kota Makassar

\begin{tabular}{ccccc}
\hline & Interval & Kategori & \multicolumn{2}{c}{ Pretest } \\
\cline { 3 - 5 } & $\mathbf{1 7 2 - 2 0 4}$ & Sangat Tinggi & F & P $(\%)$ \\
\hline $139-171$ & Tinggi & 28 & 30 \\
\hline $106-138$ & Sedang & 15 & 37,5 \\
\hline Jumlah & $\mathbf{4 0 - 7 2}$ & Rendah & 17 & 42,5 \\
\hline
\end{tabular}

Berdasarkan assesmen kebutuhan tentang model pengentasan sikap prokrastinasi akademik diperoleh beberapa hal seperti yang telah dipaparkan pada tabel 4.1 sampai dengan tabel 4.6. hasil-hasil tersebut antara lain:

a. Pada umumnya program pengentasan sikap prokrastinasi akademik belum terlaksana di sekolah secara sistematik dan terstruktur.

b. Program pengembangan model pengentasan sikap prokrastinasi akademik sangat penting diberlakukan di sekolah.

c. Dibutuhkan program pengembangan model pengentasan sikap prokrastinasi akademik dalam bentuk konseling kelompok sehingga para konseli dapat saling membentu dan memberi masukan selama proses konseling berlangsung.

d. Model pengentasan sikap prokrastinasi akademik sangat dibutuhkan di sekolah sebab pelaksanaannya akan terkendala jika tidak ada model pelaksanaan yang menjadi acuan.

Dalam pelaksanaan model pengentasan sikap prokrastinasi akademik siswa dianggap sangat penting, untuk itu maka sangat dibutuhkan sebuah model pengentasan sikap prokrastinasi akademik sehingga pelaksanaannya tidak terkendala. Berdasarkan hal tersebut maka sangatlah penting untuk mendesain dan mengembangkan sebuah model tentang model pengentasan sikap prokrastinasi akademik siswa. Model ini diharapkan dapat menjadi rujukan bagi

konselor serta siswa dalam mengembangkan prestasi akademiknya di sekolah.

Berdasarkan hasil kajian literarur tentang model pengentasan sikap prokrastinasi akademik siswa diperoleh dasar bahwa kebiasaan prokrastinasi akademik ini merupakan sebuah teknik dalam melaksanakan konseling baik itu konseling individu maupun kelompok.

\section{Gambaran Model Hipotetik Pengentasan Sikap Prokrastinasi Akademik Berbasis Cognitive Behavior Therapy}

Berdasarkan hasil assesmen kebutuhan yang dilakukan, maka didesain sebuah model teoritik/hipotetik yang di beri nama "Model Entas Proksi" yang dapat pula disebut dengan "Model Pengentasan Sikap Prokrastinasi Akademik Siswa". Model ini dapat diimplementasikan untuk meningkatkan prestasi akademik siswa di sekolah dan menghilangkan kebiasaan prokrastinasi akademik siswa di 
sekolah dan terdiri dari dua bagian yang merupakan satu kesatuan, yaitu model dan panduannya.

\section{a. Model Pengembangan Sikap Prokrastinasi Akademik Siswa Berbasis Cognitive Behavior Therapy}

Model pengentasan sikap prokrastinasi akademik siswa di sekolah ini terdiri dari dua komponen utama, yaitu komponen filosofis dan komponen operasional. Komponen filosofis berisi tentang rasional, tujuan, ruang lingkup, populasi sasaran model, asumsi dasar dan prinsip kerja model, pendukung sistem layanan model, dan peranan konselor. Sedangkan komponen operasional adalah prosedur pelaksanaan yang terdiri dari tiga sesi atau tahap yaitu tahap pra-kegiatan, kegiatan dan pascakegiatan.

\section{b. Panduan Model Pengentasan Sikap Prokrastinasi Akademik Berbasis Cognitive Behavior Therapy}

Panduan model merupakan petunjuk teknis operasional dalam mengimplementasikan model. Panduan model ini memberikan penjelasan implementatif mengenai butir-butir tahap imlementasi model.

1) Pengantar

Panduan pelaksanaan model ini berisi uraian tentang tatacara operasional dan implementasi model. Uraian operasional ditekankan pada kegiatan atau aktivitas pra-kegiatan, saat kegiatan dan pasca-kegiatan.

2) Pokok-pokok Pelaksanaan

Pelaksanaan model pengentasan sikap prokrastinasi akademik melalui tiga tahap yaitu; tahap pra-kegiatan, tahap kegiatan dan tahap pasca-kegiatan.

a) Tahap Pra-kegiatan

Tahap pra-kegiatan ini merupakan tahap perencanaan atau persiapan pelaksanaan aktivitas kegiatan. Jenis kegiatan yang dilakukan pada saat ini adalah:

(1) Identifikasi peserta

(2) Menentukan tujuan

b) Tahap Kegiatan

Tahap ini bertujuan mendorong inisiatif konseli untuk berkomunikasi dan menjalin hubungan yang baik antar anggora kelompok sehingga dalam proses kegiatan berlangsung dapat berjalan dengan baik dan lancar. Pada tahap ini ada tiga sesi, yaitu;
(1) Pengenalan kegiatan

(2) Pelaksanaan kegiatan

(3) Perenungan kegiatan

c) Tahap Pasca-kegiatan

Evaluasi adalah menilai dan mengukur tingkat keberhasilan program dan tingkat perubahan tertentu berdasarkan target tertentu. Sejatinya, evaluasi model Entas Proksi bukan hanya dilakukan pada akhir kegiatan melainkan dilakukan disetiap sesi selama proses konseling berlangsung.

\section{Gambaran Model Pengentasan Sikap Prokrastinasi Akademik Berbasis Cognitive Behavior Therapy yang Terkembangkan}

Kelayakan konseptual dan kelayakan praktis model perlu dipenuhi. Untuk kepentingan tersebut, model hipotetik-teoritik yang dihasilkan pada tahap sebelumnya, perlu dilakukan validasi isi atau konseptual dan validasi empirik atau praktisi. Validasi isi dilakukan dengan melibatkan ahli bimbingan konseling dan validasi empirik melibatkan praktisi yang terlibat langsung dalam pembinaan siswa di sekolah.

\section{a. Validasi Isi}

Berdasarkan analisis lembar validasi model diperoleh beberapa hasil dan saran untuk dipertimbangkan dalam proses mengubah atau perbaikan model. adalah sebagai berikut.

1) Kerangka Acuan Model

Berdasarkan hasil analisis pada dimensi kerangka acuan model dengan indikatorindikator tersebut menurut para ahli semuanya berada pada kategori layak. Artinya, kerangka acuan yang melandasi perumusan atau desain model memenuhi standar kelayakan teoritis atau konseptual.

2) Landasan Pengembangan Model

Hasil penilaian para ahli pada dimensi landasan pengembangan model ini berdasarkan indikator-indikator yang dinyatakan pada kategori sangat layak.

3) Keterampilan dan Daya Tarik Model

Hasil penilaian para ahli mengenai dimensi tampilan atau daya tarik model menunjukkan semua indikator dinyatakan layak bahkan sangat layak.

Namun demikian, ada beberapa saran perbaikan para pakar dalam dimensi daya tarik model ini yaitu perlunya penyesuaian gambar sampul dalam isi modul sehingga setiap orag 
yang melihat sampul dari modul dapat memiliki gambaran tentang apa yang menjadi isi dari modul tersebut. Hal tersebut akan dijadikan informasi atau bahan dalam revisi model pada tahap selanjutnya.

4) Rasional Model

Hasil penelitian para pakar tentang dimensi rasional model ini menunjukkan bahwa rasional model konseling ini sangat layak sebab disusun dengan berlandas pada kerangka teori yang jelas, merujuk pada kondisi kebutuhan konseling yang nyata, memiliki urgensi sebagai alternatif pemecahan masalah dan rumusan serta alur pikir yang dibangun dengan jelas. Hasil ini mengindikasikan bahwa pokok-pokok rumusan dimensi rasional sangat layak diguakan sebagai rasional model operasional.

Untuk kesempurnaan dimensi rasional model, para pakar menyarankan beberapa hal menjadi bahan revisi dimensi model pada langkah selanjutnya.

5) Tujuan Model

Hasil penelitian para ahli menunjukkan bahwa dimensi tujuan model berada pada kategori sangat layak. Hal ini berarti bahwa tujuan model yang dibangun berlandas pada tujuan konseling pada umumnya, mengarah pada pengembangan potensi diri siswa, mencerminkan kondisi kebutuhan konseling siswa saat ini, dan tujuan dirumuskan secara jelas dan operasional. Hasil ini mengisyaratkan bahwa tujuan model telah memenuhi syarat sebagai tujuan model konseling yang dikembangkan.

6) Ruang Lingkup Layanan Model

Para ahli menilai bahwa ruang lingkup layanan model telah memenuhi tingkat kelayakan yang dipersyaratkan. Sebab subtansi layana telah menjadi bagian yang menyatu dengan program konseling di sekolah, aspekaspek yang dikembangkan melalui layanan model telah mengarah pada pencapaian tujuan model, penggunaan kelompok sebagai adegan layanan telah sesuai, dan rumusannyapun telah jelas dan spesifik.

7) Populasi Sasaran Model

Berdasarkan pada hasil penelitian para ahli mengenal dimensi populasi sasaran model, rumusan dimensi ini sangat layak. Artinya, indikator-indikator yang membangun rumusan populasi sasaran memenuhi syarat kelayakan. Hal ini berarti bahwa rumusan populasi sasaran model telah tepat bila dilihat dari segi keleluasaan cakupan sasaran layanan, prioritas sasaran layanan yang sesuai dengan kebutuhan, sasaran layanan yang tepat, dan rumusanya yang jelas.

8) Asumsi dan perinsip kerja model

Para ahli menilai bahwa asumsi dan prinsip kerja model telah memenuhi syarat kelayakan sebagai sebuah model konseling. Sebab asumsi dan prinsip kerja telah dirumuskan dengan berlandas pada teori yang jelas, memungkinkan diimplementasikan berdasar prinsip-prinsip kerjanya, dan rumusannya jelas serta mencerminkan karakteristik model yang dibangun.

9) Asumsi dan Prinsip Kerja Model

Berdasarkan penilaian para ahli, dimensi pendukung sistem layanan model memenuhi syarat kelayakan dalam pembangunan model. Ini berarti bahwa aspek-aspek yang berkaitan dengan pengembangan program layanan, pengembagan staf, penataan kebijakan, dan penyediaan sarana pendukung telah memenuhi kelayakan.

\section{0) Peranan Konselor}

Hasil penilaian para ahli menunjukkan bahwa dimensi peranan konselor dalam model memenuhi syarat kelayakan. Layak karena peranan konselor dalam model ini memungkinkan dijalankan oleh konselor dan peranan tersebut sesuai dengan peranan konselor yang semestinya, serta rumusan yang dimilikinya sangat jelas. Namun demikian, para ahli memandang perlunya pelatihan konselor untuk dapat menjalankan peranannya dalam model ini dengan baik.

11) Perosedur Pelaksanaan

Pada umumnya ahli menyatakan bahwa prosedur pelaksanaan dalam model ini telah memenuhi syarat kelayakan. Dimensi layak sebab tahapan pelaksanaan model ini jelas; setiap tahap pelaksanaan saling berkaitan antara tahap yang satu dengan tahap yang lainnya; aktivitas setiap tahap pelaksaan jelas; kegiatan setiap tahap menunjang pencapaian tujuan dan rumusan setiap tahap operasional.

12) Evaluasi Model

Saran perbaikan dari para ahli dalam revisi model berikutnya adalah perlunya lembar evaluasi yang mampu mengukur keberhasilan implementasi model secara operasional dan lebih rinci disetiap sesi kegiatan. 
13) Panduan Pelaksanaan

Hasil penilaian para ahli menyatakan bahwa panduan pelaksanaan model telah memenuhi syarat kelayakan. Pemenuhan syarat kelayakan tersebut sebab panduan telah memudahkan dalam memahami isi modul, merupakan petunjuk teknis atau operasional model, mencakup semua aspek pelaksanaan model, dan rumusan jelas. Dengan demikian, panduan ini dapat dikategorikan layak sebagai bagian yang tidak terpisahkan dengan model.

Berdasarkan hasil validasi para ahli tentang model konseling ini dapat ditarik kesimpulan bahwa dimensi-dimensi model yang meliputi: kerangka acuan, landasan pengembangan, tampilan/daya tarik, rasional, tujuan, ruang lingkup layanan, populasi sasaran, asumsi/prinsip kerja, penduduk sistem layanan, peran konselor, prosedur pelaksanaan, evaluasi dan panduan pelaksanaan model. Para ahli juga merekomendasikan bahwa ditinjau dari segi aspek isi secara utuh model pengentasan sikap prokrastinasi akademik siswa berbasis CBT layak untuk dilanjutkan proses pengembangannya untuk dapat diimplementasikan di sekolah.

\section{b. Validasi Empirik}

Pelaksanaan validasi ini dilakukan pada 12 sekolah yang ada di kota makassar, dimana sekolah tersebut terdiri dari Sekolah Menengah Atas (SMA) sebanyak 3 sekolah, Sekolah Menengah Kejuruan (SMK) sebanyak 3 sekolah, Madrasa Aliah Negeri (MAN) sebanyak 3 sekolah, dan SMA swasta sebanyak 3 sekolah. Prosesi validasi empirik ini dimulai dengan pejelasan singkat peneliti mengenai maksud penelitian/model tersebut, memberikan kesempatan kepada validator untuk membaca/memahami model atau melakukan analisis terhadap isi model, serta pemberian lembar validasi pada validator untuk menilai kelayakan operasional model. Selai itu validator diminta utuk mensimulasikan model tersebut serta dilakukan interview mendalam oleh peneliti.

Proses validasi empirik lebih ditekankan kepada pembahasan operasional dan implementasi model. Untuk model konseling ini lebih ditekankan kepada dimensi prosedur pelaksanaan model. Prosedur pelaksanaan model terdiri atas tiga tahap, yaitu: tahap prakegiatan, tahap kegiatan, dan tahap pasca kegiatan. Para praktisi (konselor) menelaah isi prosedur pelaksanaan model, mendiskusikannya, dan menilai kemungkinan penerapannya di sekolah.

Pada validasi praktisi yang dilakukan itu juga dibahas dan didiskusikan secara mendalam tentang pembuatan "skenario layanan". Skenario layanan merupakan kegiatan operasional yang dibuat dan dilaksanakan oleh konselor dalam implementasi model pengentasan sikap prokrastinasi akademik siswa berbasis CBT (Entas Proksi). Untuk kepentingan penelitiaan ini, skenario layanan yang disusun khusus berisi kegiatan atau aktivitas yang menyangkut sikap prokrastinasi akademik.

Upaya untuk mengetahui kemungkinan operasional atau implementasi model, maka diakhir pelaksanaan kegiatan validasi empirik dilakukan pengumpulan data melalui kuesioner/lembar evaluasi kelayakan operasional atau keberterimaan model. Sedangkan dalam proses simulasi pelaksanaan model dilakukan juga pengumpulan data tentang keberterimaan konselor melalui interview dan observasi.

Hasil analisis kuesioner tingkat keberterimaan atau kemungkinan pelaksanaan model secara lengkap dipaparkan pada tabel 4.7 berikut.

Tabel 4.7: Distribusi Frekuensi dan Presentase Kelayakan Operasioal Model Menurut Konselor

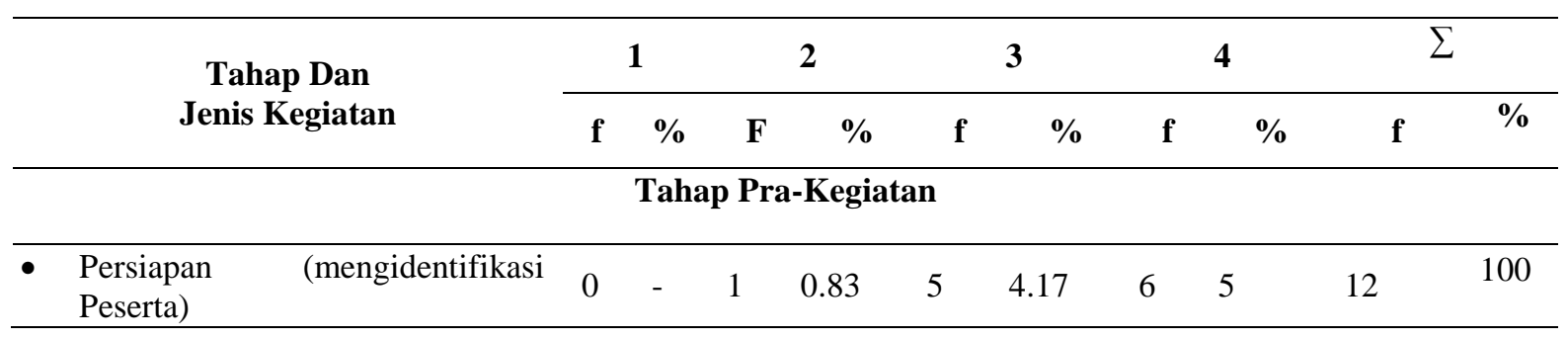




\begin{tabular}{|c|c|c|c|c|c|c|c|c|c|c|}
\hline - Merumuskan Tujuan & 0 & - & 1 & 0.83 & 6 & 5 & 5 & 4.17 & 12 & 100 \\
\hline - Pemahaman Materi & 0 & - & 0 & - & 5 & 4.17 & 7 & 5.83 & 12 & 100 \\
\hline - Memahami Skenario Pelaksanaan & 0 & - & 0 & - & 9 & 7.5 & 3 & 2.5 & 12 & 100 \\
\hline \multicolumn{11}{|c|}{ Tahap Pelaksanaan } \\
\hline - Pemberian Meteri & 0 & - & 0 & - & 7 & 5.83 & 5 & 4.17 & 12 & 100 \\
\hline \multicolumn{11}{|l|}{ - $\quad$ Pelaksanaan Teknik } \\
\hline Pengenalan & 0 & - & 0 & - & 3 & 2.5 & 9 & 6.81 & 12 & 100 \\
\hline Implementasi & 0 & - & 8 & 6.67 & 2 & 1.67 & 2 & 1.67 & 12 & 100 \\
\hline Evaluasi/Refleksi & 0 & - & 3 & 2.5 & 7 & 5.83 & 2 & 1.67 & 12 & 100 \\
\hline
\end{tabular}

Tahap Pascapelaksanaan

\begin{tabular}{|c|c|c|c|c|c|c|c|c|c|c|}
\hline - Merancang Evaluasi & 0 & - & 7 & 5.83 & 3 & 2.5 & 2 & 1.67 & 12 & 100 \\
\hline - Melaksanakan Evaluasi & 0 & - & 5 & 4.17 & 4 & 3.03 & 3 & 2.5 & 12 & 100 \\
\hline$\sum$ & 0 & - & 25 & 20.83 & 51 & 42.2 & 44 & 35.99 & 120 & 100 \\
\hline
\end{tabular}

Keterangan :

1. Tidak dapat dilaksanakan/praktikkan

2. Dapat dilaksanakan/dipraktikkan/jika dilatihkan

3. Dapat dilaksanakan/dipraktikkan setelah mempelajari mendalam

4. Segera dapat dilaksanakan/dipraktikkan

$\mathrm{F}=$ frekuensi

$\%=$ presentasi

$\sum=$ jumlah

Berdasarkan tabel diatas, terlihat bahwa penerapan model menurut para konselor kemungkinan dapat dilaksanakan setelah dipelajari secara seksama. Tetapi juga ada yang berpendapat bahwa model dapat dilaksanakan jika didahului dengan pelatihan khususnya mengenai model, dan sebagian juga merasa yakin dapat segera melaksanakan model tanpa melakukan pelatihan terlebih dahulu.

Berdasarkan hasil observasi pada tahap prakegiatan terdapat tiga kegiatan yang dinilai oleh para praktisi mengenai kemungkinan implementasinya di sekolah. Ketiga kegiatan tersebut adalah: persiapan, pemahaman materi, dan skenario, dan pengenalan kegiatan. Sedangkan dari interview kepada konselor, diperoleh keterangan bahwa mereka umumnya merasa senang dengan adaya model konseling ini. Kehadiran model ini diyakini dapat menambah khasana atau literatur tentang pelaksanaan teknik konseling di sekolah serta dapat membantu atau mempermudah konselor dalam melakukan teknik konseling khususnya model pengentasan sikap prokrastinasi akademik berbasis CBT (Entas Proksi) baik itu dalam konseling kelompok maupun individu. Menanggapi pernyataan tentang kemungkinan penerapan model ini di sekolah, pada umumnya

konselor meyakini bahwa model ini dapat mereka implementasikan. Konselor menganggap bahwa prosedur pelaksanaan model pengentasan sikap prokrastinasi akademik tidak terlalu rumit, langkah-langkah kerjanya jelas, dan menyediakan bahan-bahan yang tidak terlalu sulit untuk dipahami. Namun mereka menyatakan ada beberapa kemungkinan kendala yang mereka alami dalam mensumulasikan model ini yaitu pada penyusunan skenario layanan. Untuk itu, mereka pada umumnya menyarankan adanya pelatihan tentang penyusunan skenario layanan tersebut serta simulasinya.

Berdasarkan hal tersebut juga hasil validasi praktisi model oleh konselor di sekolah, maka 
secara keseluruhan model pengentasan sikap prokrastinasi akademik ini telah memenuhi syarat-syarat kelayakan operasional atau implementatif. Meskipun demikian, untuk mewujudkan model ini menjadi model layak operasional, maka beberapa saran dari konselor yang dijadikan bahan revisi sebelum dilakukan uji efektivitas yaitu:

1) Perlu dicantumkan alokasi waktu yang tepat untuk pelaksanaan model.

2) Perlu dirumuskan secara jelas tujuan masing-masing aktivitas/sesi dalam skenario layanan.

3) Diperlukan adanya kegiatan yang jelas untuk meningkatkan pemahaman konselor tentang implementasi model melalui pelatihan.

Model dan saran validasi empirik atau uji kelayakan operasional di atas, dijadikan dasar dalam merevisi model pengentasan sikap prokrastinasi akademik (Entas Proksi). Proses revisi model pada tahap pengembangan ini menghasilkan model operasional. Model operasional inilah yang dijadikan dasar dalam melakukan uji efektivitas model dalam upaya memperoleh model teruji serta operasional dan direkomendasikan untuk diimplementasikan di sekolah.

\section{Uji Keterlaksanaan (Simulasi Pelaksanaan)}

Proses simulasi pelaksanaan model pengentasan sikap prokrastinasi akademik ini diberikan pada 5 orang konselor sekolah. Penetapan 5 orang konselor diberikan pada pertimbangan kebutuhan tenaga konselor dalam uji efektifitas (eksperimentasi) model dan asal sekolah yang siswanya akan dijadikan peserta implementasi model. Simulasi ini difokuskan pada aspek-aspek yang terkait dengan tahap

Tabel 4.8: Hasil Observasi Pelaksanaan Teknik implementasi atau pelaksanaan model yaitu tahap pra-kegiatan, tahap kegiatan, dan tahap pasca kegiatan. Adapun penilaian yang dilakukan dalam simulasi adalah dengan menggunakan lembar observasi pelaksanaan model pengentasan sikap prokrastinasi akademik berbasis CBT (Entas Proksi) untuk merekam gambar pelaksanaan simulasi tersebut.

Hal-hal yang menjadi pokok-pokok penilaian dalam lembar observasi tersebut adalah: memulai setiap sesi dengan membagun rapport; memaparkan materi dengan aturan dan terstruktur; mengaplikasikan teknik secara tepat; memanfaatkan bahan bacaan dan lembar kerja yang disediakan dengan baik; mengajak konseli untuk aktif selama proses kegiatan berlangsung; menggunakan bahasa yang tepat selama proses kegiatan; dan pengalokasian waktu yang tepat.

Pada pelatihan konselor ini, guru pembimbing/konselor bersama peneliti sebagai fasilitator melakukan kegiatan-kegiatan berikut: (a) Latihan mengidentifikasi masalah (b) Latihan merumuskan tujuan bersama (c) Simulasi merancang materi/tahap kegiatan (d) Simulasi menyusun skenario pelaksanaan (e) Simulasi pelaksanaan model pengentasan sikap prokrastinasi akademik berbasis CBT (Entas Proksi).

Hasil dari pelatihan tersebut selanjutnya akan dinilai oleh peneliti dengan menggunakan lembar observasi penilaian melalui simulasi pelaksanaan yang akan dilakukan oleh konselor. Simulasi ini dilakukan agar peneliti mengetahui bagaimana gambaran pelaksanaan model pengentasan sikap prokrastinasi akademik berbasis CBT. Adapun hasil observasi dari simulasi pelaksanaan tersebut dapat digambarkan pada tabel berikut.

\begin{tabular}{|c|c|c|c|c|c|}
\hline \multirow{2}{*}{ Aspek Yang Di Observasi } & \multicolumn{5}{|c|}{ Peserta } \\
\hline & 1 & 2 & 3 & 4 & 5 \\
\hline \multicolumn{6}{|l|}{ Tahap Prapelaksanaan } \\
\hline - $\quad$ Persiapan & $\mathrm{B}$ & B & A & $\mathrm{B}$ & $\mathrm{C}$ \\
\hline - $\quad$ Merumuskan Tujuan & $\mathrm{B}$ & $\mathrm{B}$ & $\mathrm{B}$ & A & $\mathrm{B}$ \\
\hline \multicolumn{6}{|l|}{ Tahap Pelaksanaan } \\
\hline \multicolumn{6}{|c|}{ - $\quad$ Pelaksanaan Pemberian Materi (pengenalan, pelaksanaan, evaluasi) } \\
\hline Pengenalan prokrastinasi akademik & $\mathrm{B}$ & $\mathrm{B}$ & A & $\mathrm{B}$ & $\mathrm{B}$ \\
\hline Self management & $\mathrm{B}$ & $\mathrm{A}$ & $\mathrm{A}$ & $\mathrm{B}$ & $\mathrm{B}$ \\
\hline Manajemen waktu belajar & $\mathrm{B}$ & $\mathrm{B}$ & $\mathrm{B}$ & $\mathrm{A}$ & $\mathrm{B}$ \\
\hline Who am i & $\mathrm{B}$ & $\mathrm{B}$ & $\mathrm{B}$ & $\mathrm{B}$ & $\mathrm{B}$ \\
\hline
\end{tabular}




\begin{tabular}{|c|c|c|c|c|c|}
\hline Menjadi Perfeksionis & $\mathrm{B}$ & A & A & A & A \\
\hline \multicolumn{6}{|l|}{ Regulasi diri } \\
\hline Tahap Pascapelaksanaan & & & & & \\
\hline - $\quad$ Merancang Evaluasi & $\mathrm{C}$ & $\mathrm{B}$ & $\mathrm{C}$ & $\mathrm{B}$ & $\mathrm{B}$ \\
\hline - $\quad$ Melaksanakan Evaluasi & $\mathrm{B}$ & A & B & $\mathrm{C}$ & $\mathrm{B}$ \\
\hline $\begin{array}{l}\mathrm{a}=\text { Sangat Terampil } \\
\mathrm{b}=\text { Terampil } \\
\mathrm{c}=\text { Cukup Terampil } \\
\mathrm{d}=\text { Kurang Terampil }\end{array}$ & & & & & \\
\hline
\end{tabular}

Berdasarkan hasil simulasi pada tabel 4.8 di atas terlihat bahwa pada umumnya konselor telah terampil dalam mensimulasikan/mempraktekkan setiap aktivitas dalam penerapan model, baik itu pada tahap prapelaksanaan, pelaksanaan serta

tahap pascapelaksanaan. Hasil tersebut mengindikasikan bahwa secara keseluruhan model pengentasan sikap prokrastinasi akademik ini telah memenuhi syarat-syarat kelayakan operasional atau implementatif serta cenderung dapat diterapkan oleh konselor yang ada disekolah.

Berdasarkan hasil wawancara (interview) kepada konselor, diperoleh keterangan bahwa mereka umumnya merasa gembira dengan adanya model konseling ini. Kehadiran model ini diyakini dapat manambah khasanah atau literatur serta dapat membantu atau mempermudah konselor dalam melaksanakan model pengentasan sikap prokrastinasi akademik berbasis CBT baik itu dalam konseling kelompok maupun individu. Menanggapi pertanyaan tentang kemungkinan penerapan model ini di sekolah, pada umumnya konselor meyakini bahwa model ini dapat merka implementasikan. Menurut mereka, prosedur pelaksanaan model konseling ini tidak terlalu rumit, langkah-langkah kerjanya jelas, dan menyediakan bahan-bahan yang tidak telalu sulit. Namun mereka menyatakan ada beberapa kemungkinan kendala yang mereka alami dalam menerapkan model ini nantinya seperti ada beberapa sekolah yang belum memiliki jam BK, sehingga memungkinkan mereka untuk melaksanaan model ini diluar jam sekolah. tentang pelaksanaan teknik konseling disekolah

Skema 4.1 Model Pengentasan sikap prokrastinasi akademik yang terkembangkan

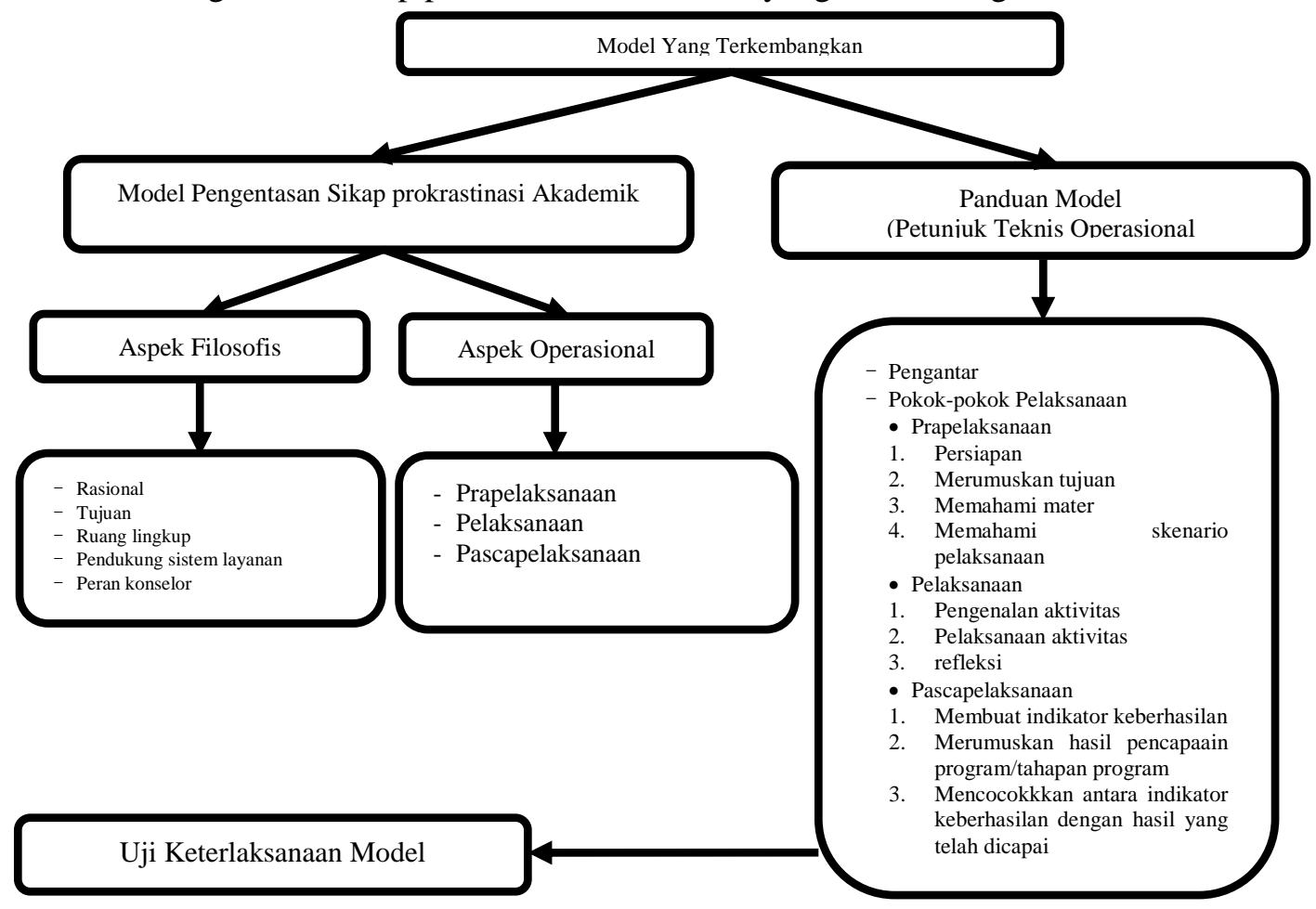


Berdasarkan proses dan hasil pengembangan model konseling tersebut maka model ini memberikan keyakinan teoritis dan empirik untuk diimplementasikan di sekolah dalam upaya menghilangkan kebiiasaan prokrastinasi akademik siswa di sekolah. Untuk itu perlu pula dipaparkan keunggulan, kelemahan/keterbatasan, peluang serta ancaman/tantangan implementasi model pengentasan sikap prokrastinasi akademik ini.

1. Keunggulan Model

Model pengentasan sikap prokrastinasi akademik memiliki beberapa keunggulan dibandingkan dengan teknik konseling lainnya. Dari perspektif koseling, model ini merupakan gabungan antara konseling kognitif dan konseling behavior, sehingga dalam proses konseling bukan hanya bertujuan untuk merubah perilaku konseli tetapi juga membantu konseli untuk menghilangkan pikiran-pikiran irasionalnya melalui pemberian beberapa materi yang secara langsung akan memperbaiki pola pikir siswa dan menghilangkan kebiasaan prokrastinasi akademiknya.

Pada tataran tertentu, program konseling yang selama ini dilakukan di sekolah bersifat monoton, membosankan, dan kurang memberi kebebasan kepada konseli untuk mengembangkan potensinya. Model pengentasan sikap prokrastinasi akademik (Entas Proksi) berorientasi pada pemberian kesempatan kepada konseli untuk bisa mengenali dirinya sendiri dan mampu menggali potesi-potensi yang dimilikinnya, model ini juga akan memberikan kesempatan kepada konseli untuk menilai dirinya sendiri apakah perilakunya saat ini mampu menunjang ketercapaian keinginanya kelak. Konseli pada model pengentasan sikap prokrastinasi akademik ini akan merasa nyaman karena disini konselor tidak akan memberikan penilaian kepada konseli sehingga konseli tidak akan merasa risih atas penilaian yang diberikan oleh konselor.

Dari perspektif outcome, konseli yang telah mengikuti setiap sesi yang ada dalam model pengentasan sikap prokrastinasi akademik, diyakini dapat menghilangkan kebiasaan prokrastinasi akademiknya dan mampu mencetak prestasi di sekolah. Sebab semua materi yang ada dalam model Entas Proksi ini bertujuan untuk memperbaiki pola pikir konseli dan mulai belajar untuk mengenali diri serta menggali potensipotensi yang dimilikinya.

\section{Keterbatasan Model}

Model pengentasan sikap prokrastinasi akademik sangat mungkin digunakan untuk mengembangkan berbagai potensi yang dimiliki oleh konseli amun secara empirik model pengentasan sikap prokrastinasi akademik baru diuji dalam menghilangkan kebiasaan prokrastinasi saja. Padahal sebuah model konseling sangat diharapkan dapat digunakan untuk mengembangkan beberapa potensi diri siswa. Kondisi inilah yang menjadi keterbatasan implementasi model konseling di sekolah. Selain dari keterbatasan tadi, model pengentasan sikap prokrastinasi akademik ini juga belum diaplikasikan secara langsung kepada siswa, hanya sebatas pengaplikasiannya kepada konselor di sekolah sehingga tingkat efektivitas model pada siswa belum bisa diukur.

\section{Peluang Serta Ancaman Implementasi Model}

Dewasa ini, permasalahan yang dialami oleh siswa di sekolah semakin kompleks sehingga sangat dibutuhkan beberapa teknik yang dapat digunakan oleh konselor untuk membantu konseli menyelesaikan masalah yang dimilikinya. Proses konseling di sekolah masih ada yang tidak sesuai dengan apa yang menjadi harapan bersama karena adanya perasaan malu yang sering dirasakan oleh siswa ketika memasuki ruang konseling seorang diri, dalam model ini konseli tidak akan lagi merasakan hal yang sama karena proses konseling disini menggunakan setting kelompok yang dimana anggota kelompok merupakan orang yag memiliki kesamaan masalah walaupun penyebab dari masalah tersebut berbeda sehingga dalam pelaksanaan model ini konseli akan memiliki kesan yang berbeda.

Melihat pemaparan tadi, maka model pengentasan sikap prokrastinasi akademik (Entas Proksi) diharapkan menjadi program konseling yang dapat membantu menghilangkan pikiran-pikiran irasional sehingga konseli mampu mengembagkan potensi dirinya. Hal inilah yang menjadi peluang pelaksanaan model konseling ini di sekolah. 
4. Tantangan Implementasi Model

Tantangan dalam pelaksanaan model ini datang dari kompetensi konselor, kompetensi konselor disini menjadi unsur penting bagi terwujudnya dengan baik tujuan dari model ini. Konselor diharapkan dapat mengetahui serta menjalankan perannya dengan baik agar tujuan dari pengembangan model ini tercapai. Dalam hal ini konselor diharapkan dapat mengidentifikasi siswa yang akan menjadi konseli untuk mengikuti model pengentasan sikap prokrastinasi ini.

Dalam hal pelaksanaan model ini, pemenuhan persyaratan kompetensi konselor menjadi tugas utama. Pemenuhan hal ini, hendaknya dilakukan melalui program yang terencana dan terstruktur. Program terencana dan terstruktur dilakukan secara berkala dengan muatan kegiatan belajar menuju tingkat kompetensi sebagaimana yang dipersyaratkan. Pola pengembangan staf seperti ini diharapkan dapat meningkatkan mutu layanan model konseling ini. Pemenuhan semua itu menjadi tantangan sekaligus ancaman bagi implementasi model ini.

\section{SIMPULAN DAN SARAN}

Merujuk pada tujuan dan tahap pengembangan, serta hasil dan pembahasan penelitian, maka dapat ditarik beberapa kesimpulan, yaitu:

1. Hasil asesmen kebutuhan tentang program pengembangan pengelolaan diri siswa dalam belajar dibeberapa sekolah di kota makassar menunjukkn bahwa:

a. Tingkat prokrastinasi akademik siswa di beberapa sekolah yang ada di kota makassar berada pada kategori tinggi

b. Pada umumnya program pengembangan model pengentasan sikap prokrastinasi akademik siswa belum terlaksana di sekolah secara sistematik dan terstruktur.

c. Program pengembangan model pengentasan sikap prokrastinasi akademik siswa sangat penting diberlakukan di sekolah.

d. Dibutuhkan suatu program untuk membantu siswa menghilangkan kebiasaan prokrastinasi akademiknya dalam bentuk konseling kelompok.

e. Modul atau panduan pelaksanaan model pengentasan sikap prokrastinasi akademik siswa berbasis CBT dibutuhkan di sekolah karena pelaksanaan program akan terkendala jika tidak ada modul pelaksanaan yang dapat dijadikan sebagai panduan/acuan.

2. Model ini disusun berdasarkan hasil need assesment yang telah dilakukan oleh peneliti. Model ini terdiri dari beberapa komponen seperti rasional, tujuan, ruang lingkup, populasi sasaran, asumsi dasar, prinsip kerja, pendukung sistem layanan, peranan konselor, prosedur pelaksanaan, evaluasi model dan panduan model. Selanjutnya model tersebut akan melalui tahap evaluasi model sehingga menjadi model yang layak secara konstruk dan operasional.

3. Model terkembangkan adalah model yang telah melalui tahap validasi model baik yang dilakukan oleh ahli BK dan praktisi di sekolah sehingga model tersebut telah teruji secara konstruk/isi maupun secara deskriptif. Berdasarkan hal tersebut maka model ini telah mengalami berbagai macam revisi berdasarkan sara serta masukan dari validatorvalidator tersebut. Model ini juga telah melalui tahap simulasi model yang dilakukan oleh konselor untuk mengetahui bagaimana gambaran pelaksanaan model di sekolah kedepannya. Karena itu, model terkembangkan yang dihasilkan dalam penelitian ini adalah model yang siap untuk digunakan di sekolah 
untuk membantu siswa dalam menghilangkan kebiasaan prokrastinasi akademik yang sering dilakukan.

Hasil penelitian ini merupakan implikasi kepada berbagai pihak sehingga direkomendasikan terhadap pengembangan ilmu pengetahuan, pemecahan masalah pendidikan, pengembangan kelembagaan dan penelitian lebih lanjut. Oleh karena itu para peneliti selanjutnya direkomendasikan untuk dapat menelaah atau mengembangkan model ini dengan sarana-sarana yang beragam. Dari kajian literatur diperoleh bahwa model ini dapat digunakan dalam mengurangi kebiasaan prokrastinasi akademik, menggali potensi yang dimiliki, serta meningkatkan keterampilan manajeman waktu dan mengembangkan sikap positif. Bagi peneliti lanjutan juga disarankan untuk dapat melakukan uji efektivitas terhadap model tersebut agar diperoleh keyakinan empirik yang tinggi terhadap model.

\section{DAFTAR RUJUKAN}

Binder, Kelly. 2000. The Effect of Academic Procrastination Treatment On Student Procrastination And Subjective well Being. (Google.com: National Library Of Canada)

Borg, W.R., Gall, M.D. (2003). Educational Reseach : An Introduction. London : Longman, Inc.

Ellis, A., Knaus, W.J. (1977). Overcoming Procrastination. New York: Institute for Rational Living.

Ferrari, J.R. Johnson, J.L. \& Mc Cown, W.G. 1995. Procrastination and Task Avoidance, Theory, Research and Treathment. New York: Plenum Press. 